\title{
EFFECT OF MOISTURE CONTENT OF GRANULATED FODDER ON ITS DOSING IN FEED STATION
}

\author{
Jaroslaw Chlebowski, Tomasz Nowakowski, Magdalena Dabrowska, Michal Sypula, Lukasz Koboska \\ Warsaw University of Life Sciences, Poland \\ jaroslaw_chlebowski@sggw.pl,tomasz_nowakowski@sggw.pl, magdalena_dabrowska@sggw.pl
}

\begin{abstract}
Currently, in animal production, increasing precision in concentrate feeding is required. The quality of dosing the feed materials is strongly influenced by their physical properties. Therefore, the aim of this study was to determine the effect of the moisture content of granulated fodder on the accuracy of its dosing in a cattle feed station. The research was carried out at the Department of Agricultural and Forestry Engineering of the Warsaw University of Life Sciences. To characterize the granulated fodder, its bulk density and mechanical durability were determined at different moisture contents. The tests of mechanical durability of fodder were determined according to the ISO 17831-1:2015 standard. To achieve the aim of this work, a cattle feed station with a spiral feeder was used. The experiments were carried out at five feeder capacities from 0.2 to $1 \mathrm{~kg} \cdot \mathrm{min}^{-1}$ for four levels of fodder moisture content in the range from 9 to $18 \%$. To determine the accuracy of dosing the fodder through the spiral feeder, the dosing accuracy indicator was determined. A statistically significant effect of the tested parameters on accuracy of dosing the fodder was shown. It was found that the increase in the moisture content of the granulated fodder increases the accuracy of its dosing. Moisture content of granules above $16 \%$ with a dosing capacity higher than $0.8 \mathrm{~kg} \cdot \mathrm{min}^{-1}$ results in accuracy of dosing of above $2 \%$. The highest value of dosing accuracy was achieved for $18 \%$ of granulate moisture content.
\end{abstract}

Keywords: granulated fodder, moisture content, dosing accuracy.

\section{Introduction}

Bulk materials in agricultural production are subject to many technological processes, such as: grinding, sorting, mixing and dosing [1]. Nowadays, animal production requires more and more precision dosing of concentrate fodders. Feed stations for animals are often equipped with volume feeders. The use of appropriate type of spiral feeder depends on the properties of the dosed material, the required efficiency and accuracy of material feeding and environmental conditions, in which the process is carried out. Volumetric dosing of bulk materials is used in processes, in which the accuracy of dosing can be greater than $5 \%$. To reach the accuracy lower than $1 \%$, the feeders cooperating with appropriate controllers regulating the speed of the motor driving the spiral feeder (gravimetric feeders) are used. The dosing of bulk materials is a process in which not only the type and construction of the feeder have a particular impact on the dosing quality, but also physical characteristics of the dosed material are very important. According to Grochowicz [2], the quality of granulated fodder depends on the characteristics of raw materials used for pressure agglomeration and their composition. On the other hand, the properties of the granulate depend in a large extent on the composition of the mixture and the binder used for its production. The main properties determining the quality and accuracy of dosing include: bulk density, porosity and moisture content [3]. In practice, frequent changes in the moisture content of the material are noticed, and the intensity of this phenomenon is caused by many external factors. The hygroscopicity of the granulate has unfavourable features during storage, transport and dosing. The softening of the granulate causes its crushing during transfer. The bulk density of granulate and ground grains decreases with increasing the moisture content [4-5]. The value of the friction force and the coefficient of external friction depend on the method of conditioning the granulated fodder during its production [6]. In addition, the value of the coefficient of external friction is influenced by the type of contacting surfaces, the speed of their movement, the contact surface area and the value of the force required for the deformation of surface irregularities [7-10]. Moreover, the external friction process is characterized by astep nature, where the displacement process can be divided into two following stages: rest and motion, which depend on the slip speed [11].

It should be noted that the conditions of dosing the materials are very diverse, because they result both from the physical state and the form of materials, as well as from the requirements regarding the rhythmicity of power supply for machines and devices [12-13].

Therefore, the aim of this study was to determine the effect of the moisture content of granulated fodder on the accuracy of its dosing in a feed station. 


\section{Materials and methods}

Tests were carried out in the Department of Agricultural and Forest Engineering at WULS. For testing the DeLaval feed station, equipped with various feeders, was used. A spiral feeder designed for dosing concentrate fodder in a loose and granular form was used for the tests. The maximum capacity of the feeder was $1 \mathrm{~kg} \cdot \mathrm{min}^{-1}$. Tests were carried out for four moisture content levels of granulate: $w_{1}=$ $9 \%, w_{2}=12 \%, w_{3}=15 \%, w_{4}=18 \%$ (these moisture contents are common for storage the fodder before feeding), at five capacities of fodder dosing: $D_{1}=0.2 \mathrm{~kg} \cdot \mathrm{min}^{-1}, D_{2}=0.4 \mathrm{~kg} \cdot \mathrm{min}^{-1}, D_{3}=0.6$ $\mathrm{kg} \cdot \mathrm{min}^{-1}, D_{4}=0.8 \mathrm{~kg} \cdot \mathrm{min}^{-1}, D_{5}=1.0 \mathrm{~kg} \cdot \mathrm{min}^{-1}$.

In order to obtain the proper moisture content of the granulate it was moisturized in the KTK 200 climate chamber. The material in climate chamber was placed in perforated bags and it was mixed every hour to obtain uniform moisture content. For each moisture content level, 10 random samples were taken and moisture content was determined by the drying-weighting method in accordance with the PN-ISO 712: 2012 standard. Before placing the samples in the drying chamber, the granules were crushed. For the moisture content level of $\mathrm{w}_{4}=18 \%$, the moisture measurement was made with the conditioning of the granulate.

The bulk density of granulated fodder was determined in five repetitions by weighting the samples with an accuracy of $0.1 \mathrm{~g}(1)$ :

$$
\rho_{g}=\frac{m-m_{p}}{V},
$$

where $\rho_{g}$ - bulk density of granulated fodder, $\mathrm{kg} \cdot \mathrm{m}^{-3}$;

$m$ - mass of container with granulated fodder, $\mathrm{kg}$;

$m_{p}-$ mass of container, $\mathrm{kg}$;

$V$ - volume of container, $\mathrm{m}^{3}$.

Length and diameter of granulate were measured using a calliper with an accuracy of $0.01 \mathrm{~mm}$. Measurements were made in 20 repetitions for 5 randomly chosen samples.

Tests of mechanical durability of fodder were made according to ISO 17831-1:2015 [14] standard and the values of mechanical durability were calculated using the following formula (2):

$$
P=\frac{m_{x}}{m} \cdot 100 \%,
$$

where $P$ - mechanical durability of tested material, \%;

$m_{x}$ - mass of granules remained on the sieve after testing, $\mathrm{g}$;

$m$ - mass of the tested sample before the test, (in amount of $300 \mathrm{~g}$ ).

To ensure the same amount of fodder in the feeding station container, the granulate was refilled after each dosing test. The dosing system was calibrated for each moisture content level of fodder used in tests. The computer program Alpro 6.4 was used for controlling the work of the feed station.

The evaluation of dosing accuracy of the feed machine consisted in determining the deviation of the received fodder portion from the set point value using the dependence (3):

$$
n_{d}=\frac{\left|w_{0}-w\right|}{w_{0}} \cdot 100 \%,
$$

where $n_{d}-$ dosing accuracy, $\%$;

$w_{0}-$ set point value (set in the program ALPRO), g;

$w$ - mass of weighed tested sample, $\mathrm{g}$.

In the control system of the feed station, the setpoint $\mathrm{w}_{0}$ equal to $0.5 \mathrm{~kg}$ has been set. This value corresponds to the planned one time amount of fodder taken by the animal using the feed station.

The correctness of the assumptions made with regard to the maintenance of a given moisture content of the granulate and the significance of differentiation of the fodder dosing accuracy in individual measurement systems was checked using statistical analysis using Statistica v.12 statistical package. 


\section{Results and discussion}

The mean moisture contents of granulated fodder for each level $\left(w_{1}, w_{2}, w_{3}, w_{4}\right)$ were: $9.05 \%$, $12.01 \%, 15.07 \%, 18.07 \%$, respectively (Table 1). On the basis of the descriptive statistics, it can be stated that granulated fodder maintained the proper moisture for all levels. The highest value of the coefficient of the moisture content variation was obtained for moisture of $w_{2}=12 \%$ and it was $1.5 \%$. For the rest of moisture content levels the value of this coefficient was in the range from 0.9 to $1.3 \%$.

Table 1

Mean values $\left(w_{s r}\right)$, standard deviation (SD) and $95 \%$ ranges for moisture content of granulated fodder $(w)$ for four moisture content levels $\left(w_{1}, w_{2}, w_{3}, w_{4}\right)$

\begin{tabular}{|c|c|c|c|c|}
\hline Moisture content & $\boldsymbol{w}_{\text {sr }} \mathbf{\%}$ & $\mathbf{S D} \boldsymbol{\%}$ & $\mathbf{- 9 5} \% \boldsymbol{w} \boldsymbol{\%}$ & $\mathbf{+ 9 5} \boldsymbol{\%} \boldsymbol{w}, \boldsymbol{\%}$ \\
\hline$w_{1}$ & 9.05 & 0.11 & 9.21 & 8.89 \\
\hline$w_{2}$ & 12.01 & 0.18 & 12.30 & 11.80 \\
\hline$w_{3}$ & 15.07 & 0.20 & 15.35 & 14.75 \\
\hline$w_{4}$ & 18.07 & 0.16 & 18.25 & 17.80 \\
\hline
\end{tabular}

The average length of fodder granules used for tests was $12.95 \mathrm{~mm}$ and their average diameter was $3.91 \mathrm{~mm}$ (Table 2).

Geometric dimensions of granules for moisture content of $9 \%$

Table 2

\begin{tabular}{|c|c|c|c|}
\hline Fodder & Sample & Length, $\mathbf{~ m m}$ & Diameter, $\mathbf{~ m m}$ \\
\hline \multirow{4}{*}{$\begin{array}{c}\text { PROAGRO } \\
- \text { Z } 18\end{array}$} & 1 & 12.53 & 3.92 \\
\cline { 2 - 4 } & 2 & 13.89 & 3.92 \\
\cline { 2 - 4 } & 3 & 12.56 & 3.90 \\
\cline { 2 - 4 } & 4 & 13.59 & 3.91 \\
\cline { 2 - 4 } & 5 & 12.18 & 3.92 \\
\cline { 2 - 4 } & average & $\mathbf{1 2 . 9 5}$ & $\mathbf{3 . 9 1}$ \\
\hline
\end{tabular}

Increase in the moisture content of granulated fodder caused decrease in its bulk density (Table 3). The test results indicate compliance with the results obtained by other authors [4-5].

Bulk density and mechanical durability of granulated fodder

Table 3

\begin{tabular}{|c|c|c|}
\hline Granulate at specific & Bulk density, $\mathbf{~ k g} \cdot \mathbf{m}^{-3}$ & Mechanical durability, \% \\
\hline$w_{1}$ (moisture content $9 \%$ ) & 703.3 & 97.6 \\
\hline$w_{2}$ (moisture content 12\%) & 677.7 & 98.2 \\
\hline$w_{3}$ (moisture content 15\%) & 607.9 & 96.8 \\
\hline$w_{4}$ (moisture content 18\%) & 558.6 & 90.1 \\
\hline
\end{tabular}

The data presented in Table 3 indicate that the moisture content of granulate affects the mechanical durability. The lowest mechanical durability was obtained at the moisture content of $18 \%$ and it was $90.1 \%$. The highest value of mechanical durability $98.2 \%$ was obtained at the moisture content of $12 \%$.

From the obtained results of the average values of the dosing accuracy of the granulated fodder (Fig. 1) it can be concluded that in the most cases, simultaneously with increase of feeder capacity, the decrease in dosing accuracy has occurred. The lowest value of dosing accuracy for single trial (the highest standard deviation from the set point value equal $2.88 \%$ ) was reached for granulate moisture content of $18 \%$ and dosing accuracy of $D_{5}=1.0 \mathrm{~kg} \cdot \mathrm{min}^{-1}$. And the highest value of dosing accuracy was obtained for the moisture content of $12 \%$ and the lowest value of feeder capacity. However, it should be noted that dosing accuracies did not differ significantly from each other at moisture content in the range from 9 to $15 \%$. The research results showed that the moisture content of granulate had an influence on the dosing accuracy, mainly at the moisture content that exceeds $15 \%$ and use of high feeder capacities (Fig. 1). Dosing of moist fodder using feeder of capacity higher than $0.8 \mathrm{~kg} \cdot \mathrm{min}^{-1}$ 
$\left(D_{3}\right)$ caused deviations in fodder dosing up to $2 \%$. This may be the result of the tendency to shredding the moist granulate at a higher rotational speed of the spiral feeder and the change in the coefficient of external friction. It is confirmed in works [15-16], in which the authors stated that the change in the moisture content of biological material has a significant influence on the friction in the area of contact between the grains of the bulk medium and the contact point of particles with the construction of the device. Therefore, the variability of friction coefficients at different moisture levels may indirectly affect the accuracy of dosing in feeding stations equipped with spiral feeders.

In order to check the significance of differentiation of feed dosing accuracy in individual measuring systems, the analysis of variance in a two-factor system was carried out. Differentiation in dosing accuracy of fodder was statistically significant for changes in the granulate moisture content and dosing capacity as indicated by the values of F-test and critical significance level P-value (Table 5). On the other hand, statistical analysis did not show a significant influence of the interaction of the studied factors on the dependent variable. For a detailed verification of the effect of the moisture content on the dosing accuracy, the Duncan's test (Table 6) was performed, which showed that there are no clear differences between mean values for the moisture content levels $w_{1}, w_{2}, w_{3}$, because the mean accuracy values belong to the same homogeneous group. A clear differentiation of dosing accuracy was found for $w_{4}$ moisture content.

Moreover, for fodder dosing capacity levels detailed statistical analysis showed the existence of three homogeneous groups. The mean dosing accuracies of the granulate did not differ significantly for $D_{2}, D_{3}$ and $D_{4}$ and for $D_{1}$ and $D_{2}$ dosing capacities. Only the dosing accuracy of the fodder for the $D_{5}$ dosing capacity differed significantly from the others.

Table 5

Analysis of variance of factors influencing the dosing accuracy of granulated fodder

\begin{tabular}{|c|c|c|c|c|c|}
\hline Source & $\begin{array}{c}\text { Sum of } \\
\text { squares }\end{array}$ & $\begin{array}{c}\text { Degrees of } \\
\text { freedom }\end{array}$ & $\begin{array}{c}\text { Mean } \\
\text { square }\end{array}$ & $\boldsymbol{F}$-test & $\boldsymbol{P}$-value \\
\hline $\begin{array}{c}\text { Moisture content } \\
\text { of granulated } \\
\text { fodder: } w\end{array}$ & 20.36 & 3 & 6.9 & 11.20 & $<0.0001$ \\
\hline Dosing capacity: $D$ & 20.82 & 4 & 5.21 & 8.59 & $<0.0001$ \\
\hline Interaction: $w \times D$ & 11.25 & 12 & 0.94 & 1.55 & 0.1070 \\
\hline
\end{tabular}

Table 6

Results of detailed statistical analysis on dosing accuracy of granulated fodder divided into homogeneous groups according to moisture content and dosing capacity (the letter ' $x$ ' means belonging to specific homogenous group)

\begin{tabular}{|c|c|c|c|c|c|}
\hline $\begin{array}{c}\text { Level of } \\
\text { factor }\end{array}$ & Size & $\begin{array}{l}\text { Mean dosing } \\
\text { accuracy, \% }\end{array}$ & \multicolumn{3}{|c|}{ Homogeneous groups } \\
\hline \multicolumn{6}{|c|}{ Moisture content of granulated fodder, $w$} \\
\hline$w_{1}$ & 75 & 1.24 & $\mathrm{x}$ & & \\
\hline$w_{2}$ & 75 & 1.37 & $\mathrm{x}$ & & \\
\hline$w_{3}$ & 75 & 1.43 & $\mathrm{x}$ & & \\
\hline$w_{4}$ & 75 & 1.92 & & $\mathrm{x}$ & \\
\hline \multicolumn{6}{|c|}{ Dosing capacity, $D$} \\
\hline$D_{1}$ & 60 & 1.13 & & $\mathrm{X}$ & \\
\hline$D_{2}$ & 60 & 1.33 & $\mathrm{x}$ & $\mathrm{x}$ & \\
\hline$D_{3}$ & 60 & 1.48 & $\mathrm{x}$ & & \\
\hline$D_{4}$ & 60 & 1.60 & $\mathrm{x}$ & & \\
\hline$D_{5}$ & 60 & 1.91 & & & $\mathrm{x}$ \\
\hline
\end{tabular}


a)

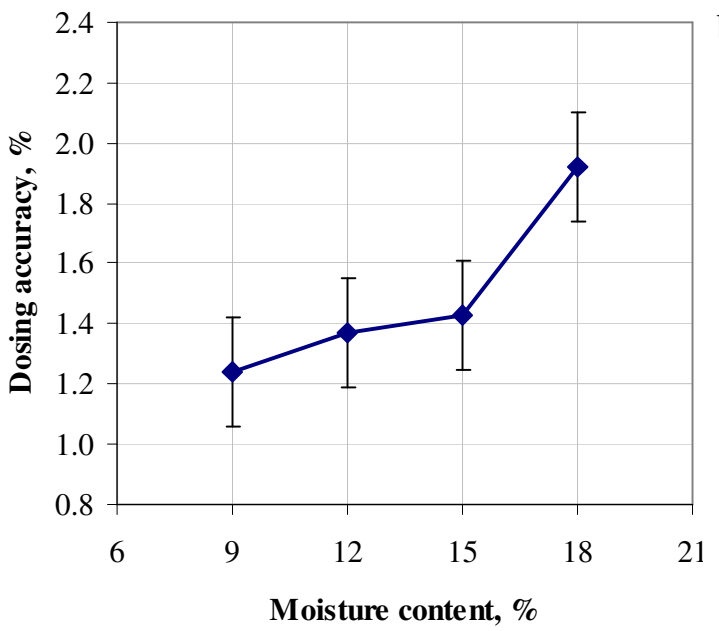

b)

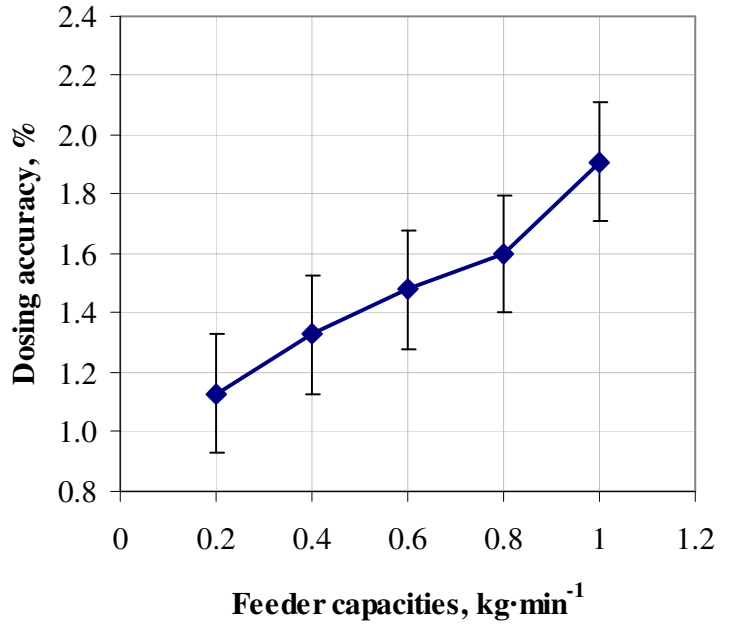

Fig. 1. Effect of moisture content (a) of granulated fodder and dosing capacity (b) on accuracy of fodder dosing

On the basis of the conducted research, it can be supposed that the reason of decrease in accuracy of dosing the moist granulated fodder may be the change in its physical properties: bulk density, internal and external friction coefficients [17] and mechanical durability. A high impact on the accuracy of fodder dosing can have a construction of a spiral feeder, in which its axis during work is set at an angle to the horizontal plane. The surface pressure of the moist granulate on the walls of the feed container and the cover of the spiral feeder at different bulk densities may be different and may affect the rhythmicity of feeding the material to the feed station $[12 ; 18]$. These phenomena may cause interference in precise feeding of moist fodder. Additional tests are required for complete explanation of the effect of the moisture content on the dosing using feed stations.

\section{Conclusions}

1. In the range from 9 to $15 \%$ of moisture content for PROARGO-Z18 granulate, the satisfying dosing accuracy of fodder (under $2 \%$ ) is obtained in the feed station equipped with the spiral feeder.

2. The change in the spiral feeder capacity affects the fodder dosing accuracy. Increase in dosing capacity causes decrease in dosing accuracy of fodder at the moisture content of $18 \%$.

3. To improve dosing accuracy of fodder in feed stations, granulate of increased moisture content $(18 \%)$ should be dosed at feed rates up to $0.8 \mathrm{~kg} \cdot \mathrm{min}^{-1}$.

4. To obtain more accurate understanding of the processes occurring during the dosing of granulated fodder at variable moisture in feed stations with spiral feeders, the investigations that have begun should be continued.

\section{References}

[1] Panasiewicz M. Postępy w technice precyzyjnego dozowania i naważania składników (Advances in precision dosing and weighingtechnology). Part I. PrzeglądZbożowo-Młynarski, 1999, pp. 41-43 (In Polish).

[2] Grochowicz J. Technologia produkcji mieszanek paszowych (Productiontechnology of mixedfeed). PWRiL, Warsaw. ISBN 83-09-01656-5, 1996. (In Polish).

[3] Opielak M. Technologiczneaspektyprocesudozowaniasypkichmateriałówrolno-spożywczych (Technological aspects of the dosing process of loose agri-food materials).Paszeprzemysłowe, 10 , 2000, pp. 12-14 (In Polish)

[4] Chung D.S., Converse H.H.Effect of moisture content on some physical properties of grains. Transactions of the ASAE 14(6), 1971, pp. 612-614.

[5] Brusewitz G.H. Density of rewetted High moisture Grains. Transactions of the ASAE 18(5), 1975, pp. 935-938. 
[6] Hebda T. Współczynnik tarcia zewnętrznego wybranych granulatów paszowych (Externalfrictioncoefficient of chosengranulatedfodders). InżynieriaRolnicza 9(118), 2009, pp. 63-71 (In Polish).

[7] Molenda M., Horabik J., Grochowicz M., Szot B. TarcieZiarnaPszenicy (Friction of wheat grain). ActaAgrophysica, 4, Pan, Lublin. 1995 pp. 1234-4125. (In Polish).

[8] Frączek J. Tarcie Ziarnistych Materiałów Roślinnych (Friction of grain plant materials). Zeszyty Naukowe Akademii Rolniczej W Krakowie. No. 252.Cracow. ISSN 1233-4189. 1999. (In Polish).

[9] Ślipek Z., Kaczorowski., Frączek J. Analiza teoretyczno-doświadczalna tarcia materiałów ziarnistych (Theoretical and experimentalanalysis of the friction of granular materials). PTIR. Cracow, ISBN 83-907553-9-4.1999. (In Polish).

[10] Frączek J., Kaczorowski J., Ślipek Z. Pomiar rzeczywistej powierzchni kontaktu trących się materiałów (Measurement of real contactarea of friction materials). InżynieriaRolnicza. No. 7(18), Cracow, 2000, pp. 55-63. (In Polish).

[11] Bucklin R. A., Molenda M., Bridges T. C., Ross I. J. Slip - Stick frictional behavior of wheat on galvanized steel. Trans. Of the ASAE, 39(2), 1996,pp. 649-653.

[12]Bolek E. Problemyautomatykiprocesudozowaniaimieszaniaskładnikówsypkich (Problems of automation in dosing and mixing processes of bulk compounds). PaszePrzemysłowe. No. 10,1997. pp. 42-46. (In Polish).

[13] Grochowicz J. Zaawansowane techniki wytwarzania przemysłowych mieszanek paszowych (Advanced techniques of industrialmixedfoddersproduction). Wydawca PAGROS s.c., Lublin.1998. (In Polish).

[14] Solid biofuels - Determination of mechanical durability of pellets and briquettes - Part 1: Pellets (ISO 17831-1:2015).

[15] Horabik J. Charakterystyka właściwości fizycznych roślinnych materiałów sypkich istotnych w procesach składowania (Characteristic of physicalproperties of plant bulk materials important in storageprocesses). ActaAgrophysica, 54,2001. (In Polish).

[16] Horabik J., Molenda M. Force and contact area of wheat grain friction, J. Agric. Eng. Res., 42, 1988, pp. 33-42.

[17] Byszewski W, Haman J. Gleba - Maszyna - Roślina (Soil-Machine-Plant). PWN Warsaw, 1977. (In Polish).

[18]Zawiślak K., Sobczak P., Panasiewicz M. Wpływ rozdrobnienia materiału na proces dozowania (Impact of shredding the material on the dosingprocess). InżynieriaRolnicza 2(111), 2009, pp. 201-205. (In Polish). 